\title{
予混合気中に分散させた燃料液滴の燃焼促進効果*
}

\author{
浜 崎豊 宏*1, 野 村 浩 司*2 \\ 氏 家 康 成 ${ }^{* 2}$, 佐 藤 順 一*3

\section{Acceleration Effects of Fuel Droplets on Flame Propagation in Partially-Prevaporized Fuel Spray} \\ Toyohiro HAMASAKI, Hiroshi NOMURA*4, \\ Yasushige UJIIE and Jun'ichi SATO \\ ${ }^{*}$ Department of Mechanical Engineering. College of Industrial Technology, Nihon University. \\ 1 2. 1 Izumi cho. Narashino shi. Chiba, 275-8575 Japan

\begin{abstract}
Fundamental studies on combustion of fuel droplet-vapor-air mixtures have been performed using a static fuel droplet cloud dispersed in fuel vapora-air premixture. Fuel droplet clouds were generated by the condensation method using rapid expansion of saturated ethanol vapor-air mixtures. Flame speed and maximum burning pressure were measured with a constant volume combustion chamber. The flame speed and the maximum burning pressure of partially-prevaporized fuel sprays are larger than those of premixtures with the same equivalence ratio on fuel-lean side. The ratio of fuel vapor and liquid in partially-prevaporized fuel sprays effects the flame speed and the maximum burning pressure. A simple one-dimensional flame propagation model was applied to explain the results. It was found that the slip velocity between fuel droplets and unburned gas and the concentration distribution of fuel vapor formed by fuel droplets play important roles in determining the flame speed.
\end{abstract}

Key Words: Partially-Prevaporized Spray, Constant-Volume Combustion, Flame Speed, Maximum Burning Pressure, Ethanol

\section{1. 粕}

噴霧燃焼は，これまでディーゼル機関やジェット機 関などに使われており，数多くの研究がなされている (1)ー(4)．高効率化を目的とした筒内直噴ガソリン機関が 開発・実用化され，ガソリン機関においても燃料液滴 が燃焼に及ぼす影響に興味が持たれる.しかしながら， その燃焼機構は非常に複雑で未だ解明されていない点 が多い，噴霧㜣焼を複雑にしている要因は多く，噴霧 中の複雑な流れ, 燃料液滴と空気の相対速度, 液滴の 偏在, 液滴直径分布の幅広さなどが挙げられる( ). 伝 播火炎に及ぼす微小燃料液滴の影響を把握するため, 燃料蒸気一空気混合気混合気中に直径分布幅の狭い静 止燃料液滴群を分散させた混合気（以下, 液滴混在混 合気）の燃焼研究が行なわれてきた(の〜の．定圧燃焼実 験において, 液滴混在混合気の火炎伝播速度が同一当 量比の燃料蒸気一空気予混合気の火炎伝播速度より速 くなる条件が存在するなどの知見が得られている(か)

* 原稿受付 2003 年 10 月 20 日。

*1 不川島検查計測 (株) (- 235.8501 横浜市磯子区新中原町 1).

*2 正員, 日本大学生産工学部(乯2 275-8575 習志野甫泉町 1-2 1).

*3 正員, 石川自播磨重工業(株) (恶1008182 東京都一代田区 大手町 2 2-1).

E mail : nomura (a cit.nihon u.ac.jp
本研究では, 得られる知見の実機への応用を考慮し, 液滴混在混合気の定容燃焼実験を行った. 予混合気中 に存在する燃料液滴が火炎伝播速度および最大燃焼圧 カに及ぼす影響を調べた.

\section{2. 実硂装置およひ方法}

$2 \cdot 1$ 液滴混在混合文生成法の原理 本実験では, 加圧した燃料蒸気一空気飽和混合気を急速膨張させる ことにより温度を急速に下げ, 混合気を過飽和状態に し, 燃料蒸気の一部を㠜集させて液滴混在混合気を生 成する. この方法は Wilson の霧箱における霧生成原 理と同じである. 混合気の急速膨張を高圧容器に取り 付けられたバルブを開放することにより行うため, 減 圧比の調節が容易, 作動時の振動が小さいおよび装置 を小型にできるなどの長所がある.

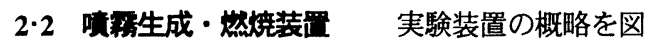
1 , 燃焼容器の詳細を図 2 に示す. 実験装置は燃焼容 器, 温度制御装置および点火装置からなる噴霧生成・ 燃焼装置と, 光学計測装置, 測温抵抗体, $\mathrm{R}$ 種熱電対 および圧力センサからなる計測装置に大別される. 燃 焼室は円筒形（直径 $40 \mathrm{~mm}$, 高さ $40 \mathrm{~mm}$ ) であり, 空 枠の窪みなども含めて容積は $66 \propto$ である. 燃狫室に 


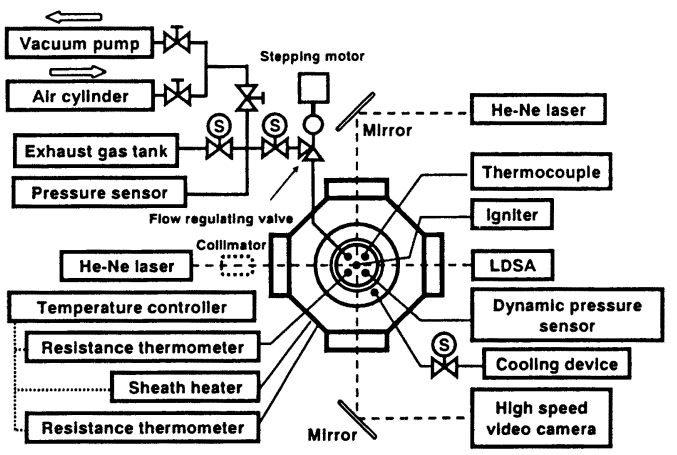

Fig. 1 Schematic diagram of the experimental apparatus.

は，直径 $20 \mathrm{~mm}$ の 2 対の観察用空を設けた，燃焼室に 高圧の燃料蒸気一空気飽和混合気を充填し, 配管の一 部に設けた排気タンクに低圧の空気を充填する. 燃焼 室と排気タンクの間に設けた $2 つ の$ 電磁弁を開くこと により, 燃焼室内を急速減圧させ, 液滴混在混合気を 生成させた. 初期減圧速度は生成される液滴混在混合 気の平均液滴直径に強く影響を及ぼす．燃焼室と排気 タンクの間に設けた流量調節弁により, 初期減圧速度 を変化させることで, 生成される液滴混在混合気の平 均液滴直径を制御した. 減圧速度減少による減圧時間 増大を防ぐため, 減圧開始 $1 \mathrm{~s}$ 後にパルスモータで流 量調節弁を全開するように設定した.

図 3は, 液滴混在混合気の空間的均一性を調べた結 果の一例である. 生成された液滴混在混合気にレー ザーシートを照射した. シートと直角方向からレー ザーの散乱光を撮影し, 燃焼室の軸に平行な幅 0.5 $\mathrm{mm}$ の直線上の輝度分布を計測した. 液滴が存在しな い部分の輝度を零とし, 輝度の平均值を 1 として示し た. 横軸の原点は燃焼室中心付近である. 散乱光強度 が液滴数密度に比例するとすれば, 液滴数密度の空間 的偏差は $1.25 \%$ であった.

全ての実験について点火直前圧力 $P_{0}$ は $0.2 \mathrm{MPa}$ で一 定とし, 減圧終了 $1 \mathrm{~s}$ 後に点火用電熱線に通電した.

点火用電熱線は, 燃焼容器のほぼ中央に設置されてい る. 火炎の伝播挙動観察には影写真法を用い, 噴霧の 平均夜滴直径の計測には, レーザー光散乱方式粒度分 布測定装置（LDSA）を用いた. LDSA は, レーザー 光の散乱を利用して液滴の粒度分布を測定する計測器 である. デフォッガを観察用空に設置することにより， 空の是りを抑制し，LDSA の計測を安定させた．燃焼 室壁冷却装置は, 減圧中の燃焼室壁から混合気への熱 流入を抑制することを目的として設置した. 冷媒には, フロン 134a を用いた. 液化されたフロンが, 燃焼室

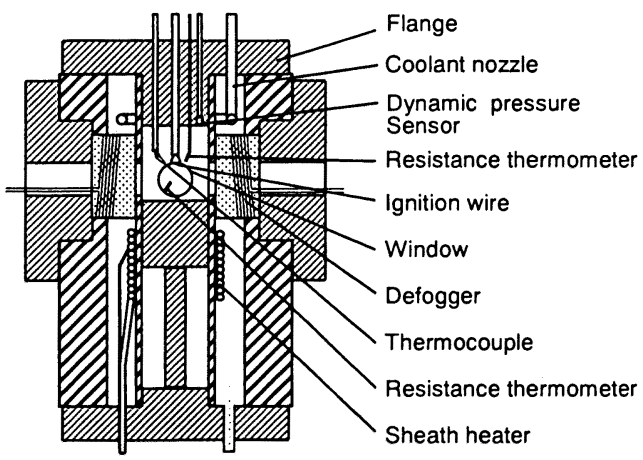

Fig. 2 Combustion chamber and high pressure chamber.

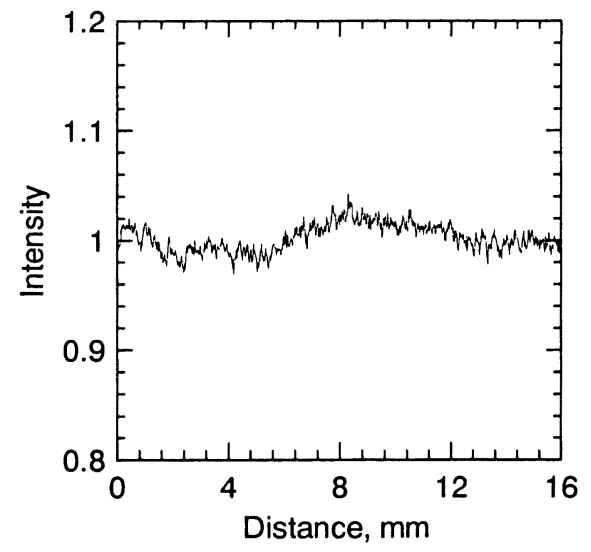

Fig.3 Intensity profile of scattered laser light from droplets along with the line parallel to the combustion chamber axis.

と高圧容器の間のジャケット部に導かれる. ジャケッ 卜部へ噴射されたフロンが気化することにより，燃焼 室壁を急速に冷却することができる.

燃料には，揮発性が適当であること，燃焼によるす すの発生が少ないことなどの理由により, 純度 99.5 vol\%のエタノールを用い， 1 回の実験で $200 \mathrm{~m} /$ 使用し た. また酸化剤には, 組成が明確でボンベごとの変動 が少ない純空気（露点 $<-60^{\circ} \mathrm{C}$ ）を用いた.

\section{3. 計測項目}

$3 \cdot 1$ 当比 混合気における燃料と空気の割合 は, 当量比を用いて示した. 液滴で存在する燃料のみ で計算した当量比を液体当量比中，蒸気で存在する燃 料のみで計算した当量比を気体当量比 $\phi_{\mathrm{g}}$, 両 者を合わせて計算した当量比を総当量比中と定義した よって, $\phi=\phi_{g}+\phi_{1}$ の関係が成立する. 本研究では減圧 前の燃料蒸気一空気飽和混合気の $\phi_{\mathrm{g}}$ が点火時での $\phi_{1}$ に 
なる. 点火直前の温度, 圧力から $\phi_{g}$ を求め, $\phi$ から差 し引くことによって， $\phi_{1}$ を求める. 総当量比および夜 体当量比を変化させるために点火直前の燃焼室温度を $290.0 \mathrm{~K}$ から $311.5 \mathrm{~K}$ の範囲で変化させたが, 上限・下 限温度とも火炎温度に比べて十分に低いため, 燃焼室 温度の変化が結果に与える影響は微小であると考え， 無視した.

$3 \cdot 2$ 液滴混在混合気の平均液滴直径 液滴混在 混合気の平均液滴直径 $d_{\mathrm{m}}$ には, ザウダー平均直径 (SMD)を用いた。累積体積がそれぞれ $10 \%$ および $90 \%$ になる液滴直径を種々の条件で調べた結果, 累積 体積 $10 \%$ は平均液滴直径の-30\%, 累積体積 $90 \%$ は+ 50\%でほぼ一定であった.

3.3 火炎伝播速度 火炎伝播速度は, 影写真法 により高速度カメラで撮影した画像から, 火炎半径の 時間変化を測定することにより求めた. 火炎半径計測 方法を図 4 に示す. 火炎半径は, 点火用電熱線を中心 に燃焼室軸方向を $0 \mathrm{deg}$ として, $-30 \mathrm{deg}$ から $30 \mathrm{deg}$ の 範囲で, $15 \mathrm{deg}$ おきに 5 方向測定し, その平均值とし た. 測定した火炎半径の時間変化を多項式で近似し， その時間微分値を火炎の移動速度とした. 図 5 は，火 炎半径の時間変化の例を, 燃料蒸気一空気予混合気と 液滴混在混合気について示している. 時刻の原点は, 点火用電熱線に通電した時刻である. 火炎は, 自立火 炎が成立するまでの遅れ時間を経た後，加速しながら 伝播し，伝播速度が一定の期間を経た後，燃焼室壁の 影響を受けて減速する. 火炎伝播速度が伝播中変化す るので, 点火用電熱線と燃焼室壁の中間点に火炎が達 する火炎半径が $10 \mathrm{~mm}$ の時点での火炎の移動速度を 代表火炎伝播速度として使用した. 火炎がしわ状にな るような条件では, 5 方向の火炎伝播速度にばらつき が生じるが，その偏差は 5\%を超えることがなかった ので, 球形火炎と同様な方法で火炎伝播速度を求めた

3.4 最大㜣嫃圧力およひ聮焼時间燃焼時の圧 力履歷の測定にはダイナミック圧力計を用いた. 圧力 履歴測定は $10 \mathrm{kHz}$ で行い，計測した圧力履歷から， 最大燃焼圧力，燃焼時間を算出した。燃焼時間は，自 立点火を確認してから，最大燃狫圧力にいたるまでの 時間と定義した。

\section{4. 火炎伝播モテル}

球状火炎伝播の場合，火炎前縁で未燃混合気が加速 するので，火炎前縁で未燃混合気と液滴の間に相対速 度（スリップ速度）が生じる. Sun, 土橋らが行った 鉄粉粒子貲霧中を伝播する火炎に関する研究において, 液滴と液滴周囲の混合気のスリップ速度によって，火

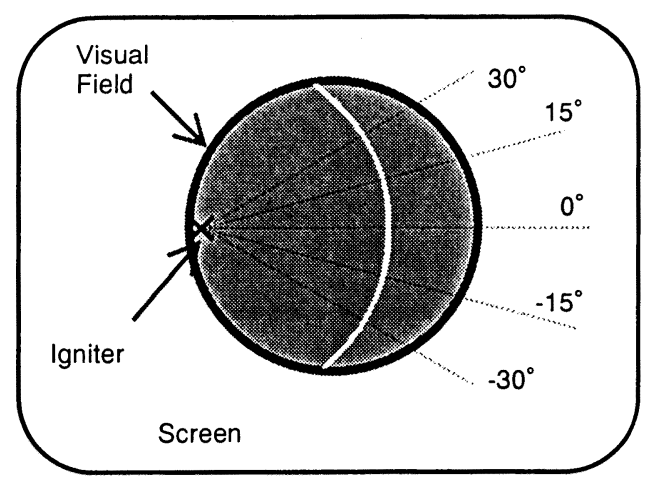

Fig. 4 Flame radius measurement.

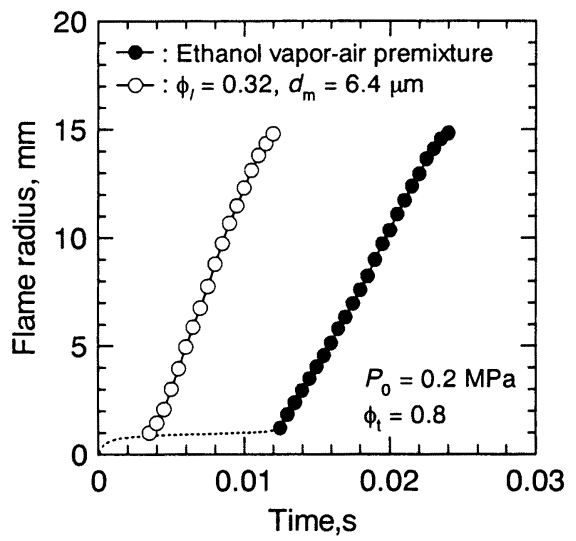

Fig.5 Temporal variations of flame radius.

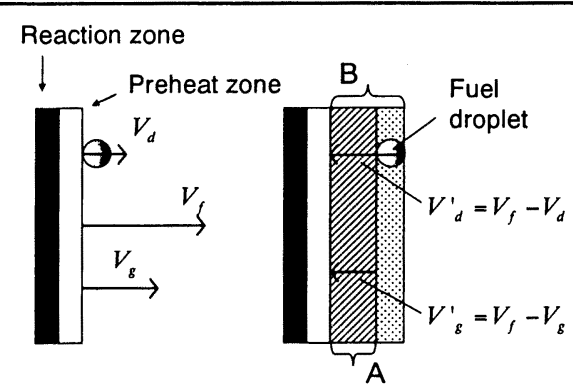

Absolute coordination Relative coordination

$V_{f}$ : Flame speed $V_{d}$ : Droplet velocity $V_{g}:$ Unburned Gas velocity

Fig. 6 Flame propagation model.

炎前縁における粒子の数密度が増大するという報告が なされているの，液滴混在混合気における球対称火炎 伝播においても, 液滴一混合気間のスリップ速度は依 存すると考えられる. 
単純な一次元火炎伝播モデルを図 6 に示す，火炎が $V_{\mathrm{f}}$ で移動しているのに対して, 未然混合気は $V_{\mathrm{g}}$ で, 液滴は $V_{\mathrm{d}}$ の速度で, 火炎から遠ざかる向きに運動す る. ただし， $V_{\mathrm{g}}$ および $V_{\mathrm{d}}$ は, 予熱帯前縁での速度と する. 火炎から見た相対座標系でみると, 火炎に向う 方向を正にとって, 燃料蒸気一空気混合気の速度 $V_{\mathrm{g}}^{\prime}$ と液滴の速度 $V_{\mathrm{d}}^{\prime}$ は

$$
V_{\mathrm{g}}{ }^{\prime}=V_{\mathrm{f}}-V_{\mathrm{g}}=S_{\mathrm{L}}, V_{\mathrm{d}}{ }^{\prime}=V_{\mathrm{f}}-V_{\mathrm{d}}
$$

となる.ここで， $S_{\mathrm{L}}$ は層流燃焼速度である．単位時間 あたりに燃料蒸気一空気混合気が予熱带に突入する体 積は, 図における A に相当するのに対して, 単位時 間あたりに予熱帯に突入する液滴群が占める空間の体 積は, 図における B に相当する. スリップ速度が存 在しない場合, 単位時間あたりに予熱帯に突入する夜 滴群が占める体積は, 燃料蒸気一空気混合気と同じ $\mathrm{A}$ である. スリップ速度が存在する場合, 液滴群は, 燃 料蒸気一空気混合気よりも(B-A)の体積分だけ多く予 熱帯に突入する. 予熱帯に突入する燃料液滴一蒸気一 空気混合気の夜体当量比を $V_{\mathrm{g}}^{\prime}$ と $V_{\mathrm{d}}^{\prime}$ の速度比を用いて 表すと, $\phi_{l} V_{\mathrm{d}}^{\prime} / V_{\mathrm{g}}^{\prime}$ となる. よって, 反応帯に入る燃料 液滴一蒸気一空気混合気の局所総当量比 $\phi^{\prime}$ は

$$
\phi_{\mathrm{t}}{ }^{\prime}=\phi_{\mathrm{g}}+\phi_{l} \frac{V_{\mathrm{d}}{ }^{\prime}}{S_{\mathrm{L}}}
$$

となる. スリップ速度 $V_{\mathrm{S}}$ は

$$
V_{\mathrm{s}}=V_{\mathrm{d}}{ }^{\prime}-V_{\mathrm{g}}{ }^{\prime}=V_{\mathrm{d}}{ }^{\prime}-S_{\mathrm{L}}
$$

であり, 式(2)および(3)から

$$
\phi_{1}{ }^{\prime}=\phi_{\mathrm{g}}+\phi_{l}\left(1+\frac{V_{\mathrm{s}}}{S_{\mathrm{L}}}\right)
$$

を得る. 平均液滴直径が増大すると液滴の慣性が強く なり， $V_{\mathrm{d}}$ が減少するため, $V_{\mathrm{S}}$ が増大する. 式(4)から, $V_{\mathrm{S}}$ の増大に伴って功増大することがわかる. また, $\phi_{l}$ の増大によっても㛺が増大する.

平均液滴直径の増大に伴う液滴群の総蒸発面積の減 少によって, 単位時間あたりに液滴から蒸発する総燃 料蒸気量が減少する. 液滴群が予熱帯で蒸発する割合 を考虑すると, (4)式は

$$
\phi_{\mathrm{g}}^{\prime}=\phi_{\mathrm{g}}+K \phi_{l}\left(1+\frac{V_{\mathrm{s}}}{S_{\mathrm{L}}}\right) .
$$

となる.ここで， $\phi_{g}^{\prime} は$ 反応带における局所気体当量比, $K$ は蒸発割合である. 液滴群が予熱帯で完全に蒸発す る場合, $K$ は 1 であり, 全く蒸発しない場合, 零であ る. $K$ の減少により, $\phi_{g}^{\prime}$ は減少する. また, 初期気体 当量比 $\phi_{\mathrm{g}}$ の減少によっても, $\phi_{\mathrm{g}}$ 'は減少する.

\section{5. 実験結果およひ考察}

$\mathbf{5 . 1}$ 火炎伝播挙動 図 7 および 8 に, $\phi=0.9$ お よび 1.4 の液滴混在混合気を伝播する火炎の連続影写 真を示す，比較のため, 燃料蒸気一空気予混合気を伝 播する火炎の写真も同時に示した. $\phi_{1}=0.9$ では, 燃料 蒸気一空気予混合気の火炎と液滴混在混合気の火炎に は, ほとんど違いがない， $\phi_{1}=1.4$ の条件では, 液滴混 在混合気の火炎がしわ状火炎になっていることがわか る. 中が増大すると, このようなしわ状火炎になりや すい傾向にある. しわ状火炎を形成する要因として, 選択拡散が考えられる. 選択拡散は気体分子の拡散速 度が異なることに起因し, 燃料および酸化剂の拡散速

(a)

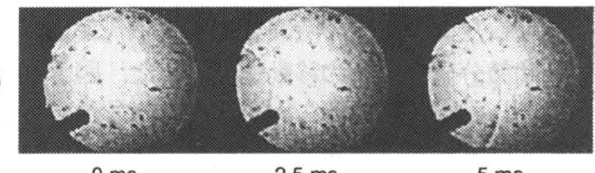

(b)

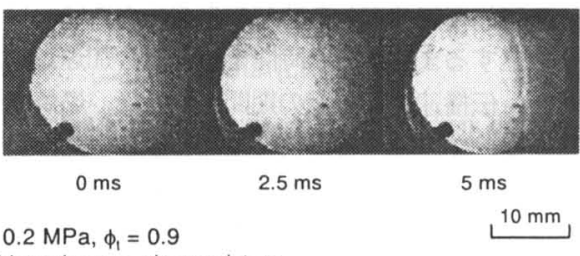

(a) Ethanol vapor-air premixture

(b) Ethanol droplet-vapor-air mixture, $\phi_{1}=0.19, d_{m}=6.5 \mu \mathrm{m}$

Fig. 7 Flame propagation behavior on fuel-lean side.

(a)

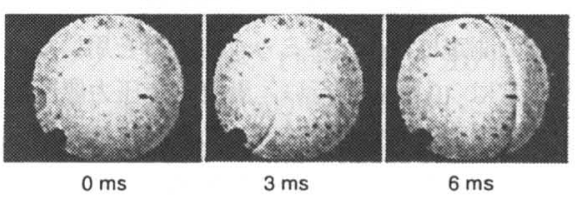

(b)

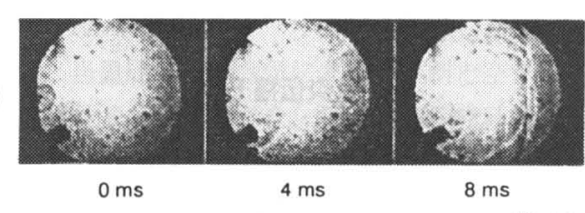

$P_{0}=0.2 \mathrm{MPa}, \phi_{1}=1.4$

$10 \mathrm{~mm}$

(a) Ethanol vapor-air premixture

(b) Ethanol droplet-vapor-air mixture, $\phi_{1}=0.20, d_{m}=6.6 \mu \mathrm{m}$

Fig. 8 Flame propagation behavior on fuel-rich side. 


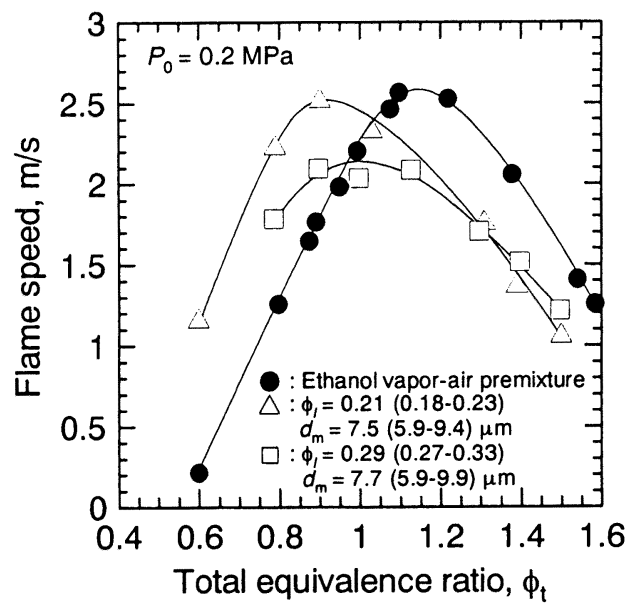

Fig. 9 Effect of total equivalence ratio on flame speed.

度の差が大きいと選択拡散の効果が大きいとされてい る. 液滴混在混合気の場合, 燃料蒸気の一部が液化し たことにより, 燃料の拡散は遅くなる. よって, 燃料 と酸化剤の拡散速度の差が大きくなるため, しわ状火 炎を形成すると考えられる. 火炎凸部には酸化剤が燃 料より多く拡散し, 凹部の局所総当量比が増大するた め, 過濃側ではしわ状火炎が発生しやすいと考えられ る.

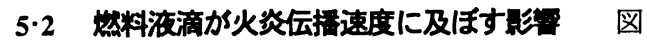
9 に, 平均液滴直径を約 $7.6 \mu \mathrm{m}$, 液体当量比を 0.21 お よび 0.29 で一定とし, 総当量比を変化させた場合の 燃料蒸気一空気予混合気および液滴混在混合気の火炎 伝播速度を示す. $d_{\mathrm{m}}$ に 5.9 9.9 $\mu \mathrm{m}$ の幅があるが, こ の範囲での $d_{\mathrm{m}}$ の変化が火炎伝播に与える影響は比較 的少ない(10). 液滴混在混合気を伝播する火炎の速度は, 燃料蒸気一空気予混合気の火炎伝播速度の場合之同様 に, фが増大するのに伴って増大し, 最大值をとった 後, 減少する. 火炎伝播速度が最大になる $\phi_{1}$ は燃料蒸 気一空気予混合気の場合と比較して小さくなり, 液体 当量比 0.21 の場合は $\phi_{1}=0.9$ 付近で, 液体当量比 0.29 の 場合は $\phi=1$ 付近である. 液滴混在混合気の火炎伝播 速度の最大值が燃料蒸気一空気予混合気の火炎伝播速 度の最大値より希薄側に移動するのは, スリップ速度 の影響により火炎面の局所気体当量比が増大したため と考えられる. 液体当量比 0.21 の場合と 0.29 の場合 を比較すると, $\phi_{1}<1.3$ の範囲では液体当量比 0.21 の火 炎伝播速度が液体当量比 0.29 の火炎伝播速度を上回 り, $\phi>1.3$ では大小関係が逆転する. また, 液体当量 比 0.29 の最大火炎伝播速度は液体当量比 0.21 のそれ と比較して値が小さい. これらの事実より, 液体当量

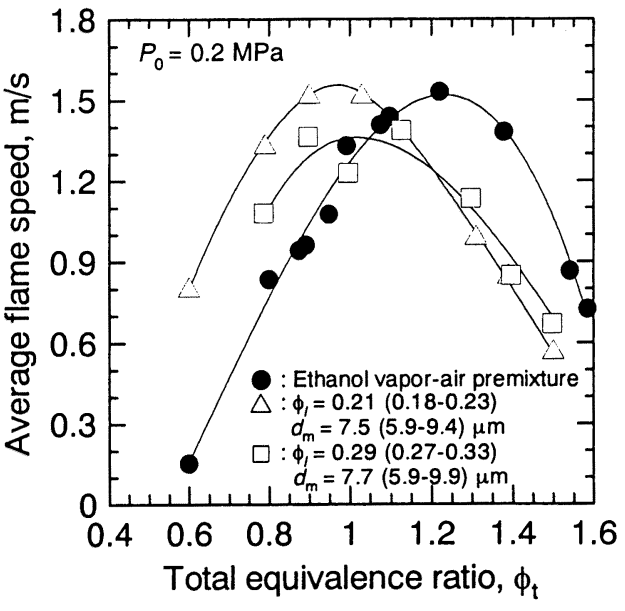

Fig. 10 Effect of total equivalence ratio on average flame speed.

比の増大に伴う蒸発潜熱の増大によって火炎温度が低 下していること，および初期気体当量比の減少によっ て反応帯前縁での局所気体当量比が減少していること が示唆される.

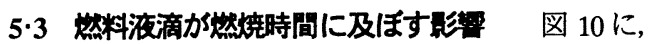
図 9 と同一実験において燃料蒸気一空気予混合気およ び液滴混在混合気の燃焼時間を計測した結果を示す.

考察を行いやすくするため，燃焼時間の逆数に燃焼室 容積と同じ容積を持つ球の半径（= $25 \mathrm{~mm}$ ）を掛けた 值, 即ち平均火炎伝播速度を燃焼時間の代わりに用い ることにする. 液滴混在混合気の平均火炎伝播速度は, 燃料蒸気一空気予混合気の場合と同様に，中が増大す るのに伴って増大し, 最小值をとった後, 減少する. 平均火炎伝播速度が最大となる $\phi_{1}$ は, 燃料蒸気一空気 予混合気の場合と比較して小さくなる. 図 9 および 10 から, 燃料蒸気一空気予混合気の場合も液滴混在 混合気の場合も，火炎半径 $10 \mathrm{~mm}$ の時点での火炎伝 播速度增大がそのまま平均火炎伝播速度の増大, 即ち 燃焼時間の短縮に結びつくことがわかる.

\section{4 然料液滴か最大然娃圧力に及ぼす影管 図}

11 に, 図 9 と同一実験で得られた燃料蒸気一空気予 混合気および液滴混在混合気の最大燃焼圧力と総当量 比の関係を示す. 最大燃焼圧力は, 最大燃焼圧力 $P_{\text {max }}$ を点火直前圧力 $P_{0}$ で除した無次元量で表した．液滴 混在混合気の最大燃焼圧力比は, 燃料蒸気一空気予混 合気の場合と同様に， $\phi_{1}$ が増大するのに伴って増大し， 最大値をとった後, 減少する. 最大燃焼圧力比が最大 となる中は, 燃料蒸気一空気予混合気の場合と比較し て小さくなる. 最大燃焼王力の最大值は, 燃料蒸気一 空気予混合気と比較して $9 \%$ 程度大きくなる. 液滴混 


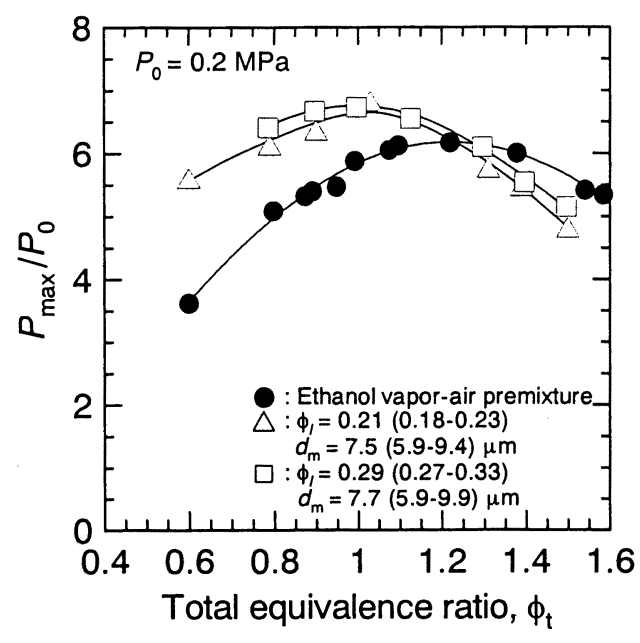

Fig. 11 Effect of total equivalence ratio on dimensionless maximum burning pressure.

在混合気の最大燃焼圧力が同一当量比の燃料蒸気一空 気予混合気の值と異なっているのは, 燃料の一部が夜 化したことおよび初期温度が低いことによる容積効率 の増大と, 燃焼時間の変化による熱損失の変化が要因 と考えられる.ここでの容積効率は, 同一総当量比・ 圧力の燃料蒸気一空気予混合気の場合に比較して何倍 の空気が燃焼室内に充填されているかを示している. 液体当量比一定の場合, 容積効率は総当量比の增大に 伴って減少する. 液体当量比 0.21 の場合, 容積効率 の増大により液滴混在混合気の最大燃焼圧力は同一当 量比の燃料蒸気一空気予混合気と比較して 3 5\% (全 デー夕平均で約 $4.1 \%$ ）増大する. 液体当量比 0.29 の 場合, 4 8\%（平均約 55\%）增大する. 一方, 熱損失 はほぼ然焼時間により決定されると考えられる. 燃料 蒸気一空気予混合気と液滴混在混合気の燃焼時間を比 較すると, 希薄側では, 液滴混在混合気の燃焼時間が 燃料蒸気一空気予混合気に対して減少し, 過濃側では 增大する. 以上より, 液滴混在混合気の最大燃狫圧力 の総当量比依存性を示す曲線は, 燃料蒸気一空気予混 合気の曲線に比べて希薄側で増大, 過濃側で減少した 曲線となり, 容積効率增大の効果が加わることによっ て, その曲線が全体的に上に移動したと考えられる.

同一当量比の燃料蒸気一空気予混合気に対する最大 燃焼圧力の増大率 $R_{\mathrm{MBP}}$ と平均火炎伝播速度の增大率 $R_{\mathrm{AFS}}$ の相関を図 12 に示す. 液滴混在混合気の最大燃 焼圧力については, 容積効率増大の補正を行い, 燃料 蒸気一空気予混合気の最大㜣焼圧力と条件をそろえた. $R_{\mathrm{MBP}}$ と $R_{\mathrm{AFS}}$ の間に強い相関があることがわかる. 最大

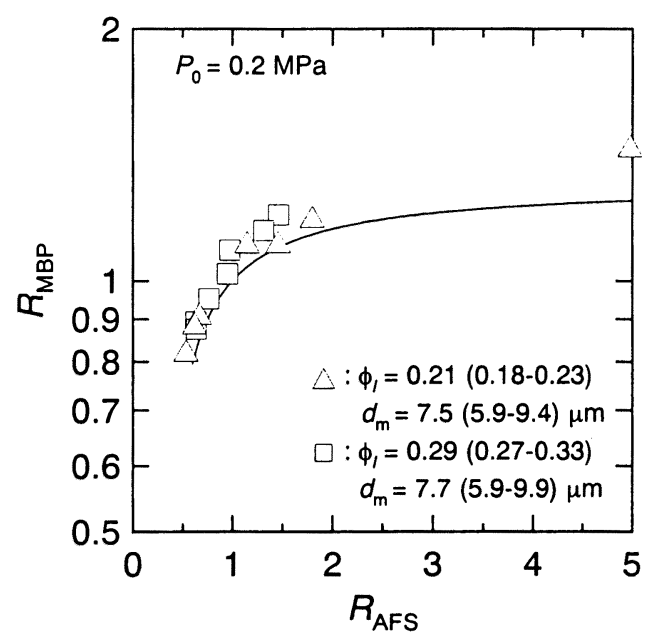

Fig. 12 Correlation of the increasing ratios of flame speed and maximum burning pressure.

燃焼圧力が正味発熱量（=燃焼による発熱から熱損失 を差し引いた值）に比例し，熱損失が燃焼による発熱 量と燃焼時間に比例すると仮定すると， $R_{\mathrm{MBP}}$ と $R_{\mathrm{AFS}}$ の間には次の関係が成り立つ.

$$
R_{\mathrm{MBP}}=\frac{\Delta h_{\mathrm{S}}\left(1-a R_{\mathrm{AFS}}^{-1}\right)}{\Delta h_{\mathrm{P}}(1-a)}
$$

ここで, $a$ は熱損失と発熱量の比であり， $\Delta h_{\mathrm{S}}$ と $\Delta h_{\mathrm{P}}$ は それぞれ液滴混在混合気および然料蒸気一空気予混合 気の燃焼熱である. $R_{\mathrm{MBP}}$ は同一総当量比の液滴混在混 合気と燃料蒸気一空気予混合気の最大燃焼圧力の比で あり, 体積効率の変化の補正も行っているので, $\Delta h_{\mathrm{S}}$ と $\Delta h_{\mathrm{P}}$ は等しいとして次式を得る.

$$
R_{\mathrm{MBP}}=\frac{1-a R_{\mathrm{AFS}}^{-1}}{1-a}
$$

$a$ を未知定数として全データから最小自乗法により求 めた結果が, 図中に示された曲線である. 非常に単純 化された熱損失モデルではあるが, 実験結果の大まか な傾向を説明していることがわかる. $R_{\mathrm{AFS}}$ が最も大き いデー夕点が曲線上にのらないのは, 火炎伝播速度が 非常に遅いため, ここで用いた熱損失モデルが適用で きないからだと考えられる. 以上より，液滴混在混合 気の最大燃焼圧力が同一当量比の燃料蒸気一空気予混 合気のそれと比較して增減する要因が，燃焼時間の減 少・增大による熱損失の減少・增大であることがわ かった. また, $R_{\mathrm{AFS}}$ が1より大きい領域, 即ち液滴混 


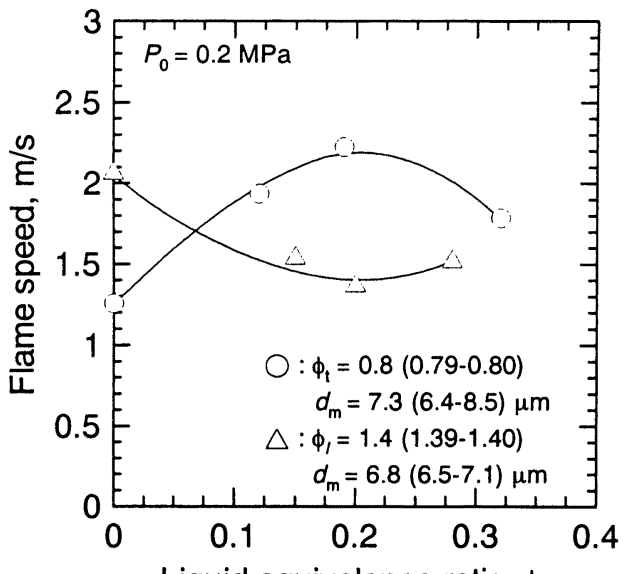

Liquid equivalence ratio, $\phi_{\text {, }}$

Fig.13 Effect of liquid equivalence ratio on flame speed.

在混合気の平均火炎速度が燃料蒸気一空気予混合気の それを上回る領域では，スリップ速度の効果がより強 く現れる $\phi_{i}=0.29$ のデー夕点の方が $\phi_{t}=0.21$ のデー夕点 より若干上方に分布していることがわかる. 液滴混在 混合気の場合, スリップ速度の効果により, 火炎伝播 後期の反応帯局所総当量比は前期に比較して希薄側に 移行する. $R_{\mathrm{AFS}}$ が 1 より大きくなるような希薄液滴混 在混合気の場合, 燃焼室壁付近で燃焼室中心より希薄 燃焼することが熱損失を低減している可能性が示唆さ れる.

5.5 液体当吾比が火炎伝播速度に及ぼす影霓 総当量比を 0.8 および 1.4, 平均液滴直径を約 $7 \mu \mathrm{m}$ で 一定とし, 火炎伝播速度の液体当量比依存性を調べた 結果を図 13 に示す. 液体当量比が零の火炎伝播速度 は, 同一総当量比の燃料蒸気一空気予混合気の值であ る. 総当量比 0.8 の場合, 液体当量比の増大に伴って 火炎伝播速度は增大し, その後減少する. 一方, 総当 量比 1.4 の場合, 火炎伝播速度は液体当量比の増大に 伴って減少し，その後増大する. 4章に示した式(5) では, 同一総当量比・液滴直径の条件では, 液体当量 比が増大すると単純に局所気体当量比も増大する結果 となる. しかしながら, 本結果は火炎前縁での局所気 体当量比が液体当量比の増大と伴に増大し, その後減 少することを示唆した. 液体当量比增大に伴う局所気 体当量比の減少の原因は, 燃料蒸気の拡散速度が有限 であることによって反応帯燃料蒸気濃度の不均一性が 液体当量比の增大により強くなり, 液滴間を満たす混 合気の当量比が減少したからと推察される.

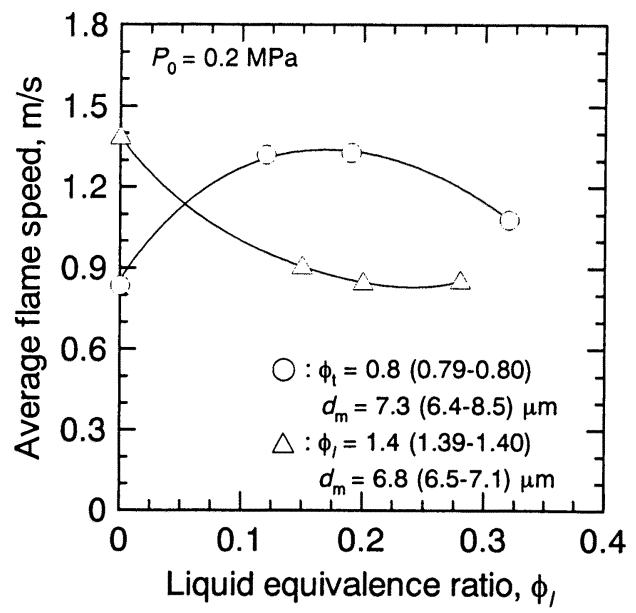

Fig.14 Effect of liquid equivalence ratio on average flame speed.

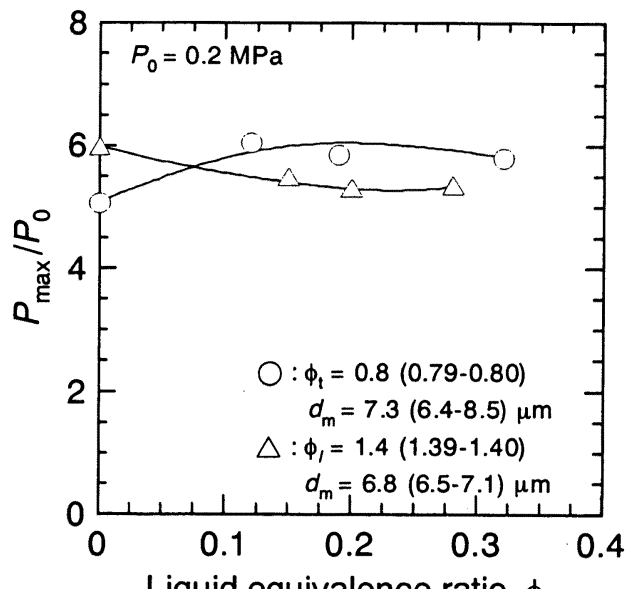

Fig. 15 Effect of liquid equivalence ratio on dimensionless maximum burning pressure.

5.6 液体当此が燃娃時間に及ほすす影需 図 14 に, 図 13 と同一実験から得られた液滴混在混合気の 燃焼時間液体当量比依存性を示す。図 10 の場合之同 様, 燃焼封間の逆数に比例する平均火炎伝播速度で結 果を示した. 液体当量比の増大に伴い, 希薄液滴混在 混合気の場合, 平均火炎伝播速度は増大し, その後減 少する. 過濃液滴混在混合気の場合, 平均火炎伝播速 度は減少し，その後增大する. 極大値・極小值を示す 液体当量比が若干異なってはいるが, 総当量比を変化 させた場合と同様に液体当量比を変化させた場合も, 
火炎半径 $10 \mathrm{~mm}$ における火炎伝播速度の増大が燃焼 時間の短縮に結びつくことがわかる.

$5 \cdot 7$ 液体当量比が最大燃焼圧力に及ほす影整 図 15 に, 図 13 と同一実験から得られた液滴混在混合 気の最大燃焼圧力を示す. 最大燃焼圧力 $P_{\text {max }}$ は, 容積 効率増大の補正を行い, 図 11 と同様, 点火直前圧力 $P_{0}$ で除した無次元量で表した. 最大燃焼圧力の液体当 量比依存性は, 変動割合は小さいが, 平均火炎伝播速 度が液体当量比対して示す依存性と同じであり, 燃焼 時間が減少したことによって熱損失が減少したと考え られる.

\section{6. 結 言}

予混合気中に分散させた燃料液滴の燃焼促進効果に ついて, 定容燃焼容器を用いて燃焼実験を行った. 総 当量比および液体当量比を変化させ, 部分予蒸発噴霧 を伝播する火炎の速度と最大燃焼圧力の計測を行った. 得られた知見を以下に示す.

(1) 液滴混在混合気の火炎は, 総当量比の増大に 伴ってしわ状になる傾向がある.

(2) 燃料蒸気の一部を液化することにより, 希薄領 域において火炎伝播速度および最大燃狫圧力は同一当 量比の燃料蒸気一空気予混合気より増大する. 本報告 の実験条件では, 希薄領域全般で燃焼促進効果が認め られた。

(3) 液滴混在混合気の火炎伝播速度および最大燃焼 圧力は, 液体当量比に依存する. 両者の液体当量比依 存性は定性的に一致する.

(4) 液滴混在混合気の最大燃焼圧力が同一当量比の 燃料蒸気一空気予混合気のそれと比較して増減する要 因は, 燃焼時間の減少・増大による熱損失の減少・増 大であることがわかった.

\section{锹辞}

本研究は，財）日本宇宙フォーラムが推進してい る「宇宙環境利用に関する地上研究公募」プロジェク
トの一環として行ったものである.ここに感謝の意を 表す.

\section{考文献}

(1) Tushima, S., Saito, H., Akamatu, F., and Katuki, M.., Journal of JSME, Vol. 66, p. 2734 (2000).

(2) Yoshida, H., Arai, M., Hiroyuki, H., and Yokoya, H., Journal of JSME, Vol. 57, p. 2416 (1991).

(3) Burgoyne, J. H. and Cohen, L., Proc. Roy. Soc., Vol. A225, p. 375 (1954).

(4) Hayashi, S., Ohtani, T., linuma, K, and Kumagai, S., The Combust. Inst., Vol. 18, p. 361 (1981).

（5）新井雅隆・天谷賢览ら，アドマイゼーショ ン・テクノロジー, 森北出版,(株), 東京 (2001).

(6) Hayashi, S. and Kumagai, S., The Proc. Combust. Inst., Vol 15, p. 445 (1975).

(7) Nomura, H., Izawa, I., Ujiie, Y., Sato, J., Marutani, Y., Kono, M., and Kawasaki, H., The Proc. Combust. Inst., Vol 27, p. 2667 (1998).

(8) Nomura, H., Koyama, M., Miyamoto, H., Ujuie, Y., Sato, J., Kono, and M., Yoda, S., The Proc. Combust. Inst., Vol. 28, p. 999 (2000).

(9) Sun, J., Dobashi, R., and Hirano, T., Seventeenth International Colloquium on the Dynamics of Explosions and Reactive Systems, Heidelberg, Germany, (1999).

(10) Nomura, H., Hamasaki, T., Kawasumi, I., Ujiie, Y., and Sato, J., SAE Paper, \#2003-01-0628 (2003). 